\title{
Den goda familjen och den goda familjerätten. Debatter om lag och moral i det mångkulturella Europa ${ }^{1}$
}

\section{ANNIKA RABO}

En central föreställning om den moderna nationalstaten är att den är juridiskt suverän inom det egna territoriet. De senaste decenniernas stora politiska och sociala förändringar har dock gjort gränserna porösare mellan olika territoriella enheter. Överstatliga organisationer som EU och FN har bidragit till att transformera staternas oavhängighet i frågor som har att göra med lag och rätt. Men även migration och framväxten av mångkulturella samhällen sätter självklara rättsliga och moraliska uppfattningar om "rätt" och "fel" på spel. I artikeln diskuterar jag, ur socialantropologisk synvinkel, hur religiöst partikulära synsätt kring centrala sociala institutioner som familj och äktenskap utmanar statens universella anspråk på oavhängighet i frågor om moral och juridik.

Den som söker information på Internet om familjeåterförening till Norge hamnar snabbt på en hemsida från den norska ambassaden i Pakistan och finner då denna

Annika Rabo, professor, Socialantropologiska institutionen, Stockholms universitet. (från engelskan fritt översatta) förmaning:

1 Material till denna artikel är insamlat under arbete i projektet Debating family law in multicultural Syria, finansierat av SAREC och projektet Familj och familjerätt bland transnationella syrier, finansierat av Vetenskapsrådet. 
"Att flytta till ett annat land betyder nya möjligheter och oförutsedda utmaningar. Kunskap och information om det nya landet är en viktig faktor för att fä ett så bra liv som möjligt. Tyvärr finns det människor som kommer till Norge och hamnar i svåra situationer. Då är det bra att veta vad man skall göra. Följande information tar upp några av de problem som kan uppstå för folk som flyttar till Norge». ${ }^{2}$

Efter detta följer en lista med följande innehåll:

- Lagar: Norsk lag gäller för alla som bor i Norge.

- Giftermål: Polygami är förbjudet.

- Tvångsäktenskap: Bara giftermål som har ingåtts frivilligt av båda parter erkänns i Norge. Tvångsäktenskap är straffbart.

- Skilsmässa: Kvinnor och män har lika rättigheter till skilsmässa

- Barn: Barn har egna rättigheter i Norge.

- Våld: Alla som utsätts för våld har rätt att få stöd från norska myndigheter. Detta gäller också de som har utsatts för våld av familjemedlemmar.

Vad säger denna information och vem är den avsedd för? Textens problemformulering och den förklarande listan sätter klara och tydliga gränser för den goda norska familjen och den goda norska familjerät-

2 All information om denna hemsida är hämtad från www.norway.org.pk/misc/print. aspx?article. Sökvägen är: Information to family reunification applicants, Norway. Informationen hämtad 2009-07-17. ten. ${ }^{3}$ I Norge har man bara en fru, och där väljer brud och brudgum varandra. Ingen hindrar sin partner från att lämna äktenskapet och barn är inte en förlängning av sina föräldrar. Våld inom familjen accepteras inte. Den som inte följer dessa påbud är en brottsling. Informationen är självklart avsedd för dem som via den norska ambassaden i Pakistan tänker ansöka om familjeåterförening i Norge. Texten är en varning till framförallt pakistanska medborgare men kanske även till medborgare från närliggande länder. Information kan också sägas rikta sig mer diffust utåt till personer som, liksom jag, söker kunskap om det norska regelverket. Men informationen riktar sig även till en norsk allmänhet och den skapar och bekräftar därmed också inåt bilden av det norska goda. Texten säger: "så här är vi«. Hemsidan kommunicerar vidare att man i Norge inte kan förvänta sig att alla som söker familjeåterförening delar denna syn på familjen. Muslimska män i allmänhet och pakistanska i synnerhet misstänkliggörs.

Den här hemsidan och dess olika budskap fångar in mycket av samtida debatter om familj, lag och moral i det mångkulturella Europa. Innehållet i debatterna om den goda familjen och den goda familjerätten (i vid bemärkelse) skiftar från land till land, men själva debatten tycks bli allt viktigare i kommunikationen mellan Europa och många länder i Asien och Afrika. Vidare är det framförallt muslimska invandrare eller medborgare som får symbolisera det främ-

3 Någon officiell hemsida om familjeanknytning liknande den norska har jag inte funnit, men det svenska regelverket är snarlikt det norska.

Annika Rabo: Den goda familjen och den goda familjerätten. 
mande och hotfulla. I Frankrike har hijab - den islamiska kvinnliga huvudduken blivit en symbol för frågan om muslimers plats i offentligheten. I England är det istället frågan om tvångsäktenskap och muslimska domstolar som väckt starka känslor och i de svenska debatterna är begreppet "hedersvåld" centralt.

Med utgångspunkt i några problemområden från den norska listan - giftermål, polygami, tvångsäktenskap, skilsmässa och barn, samt frågan om inhemsk eller främmande lag - kommer jag i denna artikel att diskutera frågor som är centrala inte bara $i$ Norge utan i hela det samtida Europa präglat av ökad rörlighet över nationella gränser och av frågor om tillhörighet. För att spegla några av dessa debatter kommer jag att göra några nedslag runt om i Europa och Mellanöstern. Artikelns syfte är inte att bestämma vad som är den goda familjen eller den goda familjerätten utan snarare att visa på den enorma komplexiteten i frågorna.

\section{Äktenskap som universell institution med olika former}

I hela världen finns skrivna eller oskrivna regler för hur och vilka som kan ingå ett äktenskap samt vilka rättigheter och skyldigheter parterna har. Dessa lagar har generellt blivit mer liberala och reglerna har blivit färre, men ingenstans uppfattas äktenskap som enbart en privatsak. Samhället och staten lägger sig i. I de medeltida nordiska samhällena kämpade företrädare för sedvanerätten och kyrkans kanoniska rätt om kontrollen över äktenskapet. I sed- vanerätten var det ätten och senare husbonden som hade vidsträckt inflytande över förhandlingar och kontrakt. Äktenskapet var alltför viktigt - både ekonomiskt och socialt - för att låta brud och brudgum fatta egna beslut. Men kyrkans kamp mot sedvanerätten var lång och först 1734 fick kyrkan i Sverige monopol på rättsligt erkända äktenskap (Inger 1980 s. 140). Kyrkans makt inskränkte släktens och husbondens, men kom också att föra med sig en mer reglerad syn på sexualitet (Melby et al. 2006 s. 27). Och eftersom kyrka och stat var intimt förenade i Sverige kom också staten att få ett ökat inflytande över familjerätten. Från mitten av 1800-talet intensifierades diskussionerna om att göra man och hustru mer likställda inom äktenskapet och 1915 fick Sverige en ny modern äktenskapslag. Reformarbetet var ett resultat av ett gemensamt nordisk engagemang och de andra länderna följde snart med liknande reformer.

\section{Reglering av och restriktioner kringäktenskap}

Att staten får ett ökat inflytande över att reglera, kodifiera och erkänna äktenskap, på bekostnad av släkt eller religiösa institutioner, har vi sett på de flesta håll i världen, inte minst genom framväxten av nationalistiska rörelser. Så har också skett i Mellanöstern, ofta med utgångspunkt från klassisk islamisk juridik. Efter islams uppkomst på 600-talet växte olika så kallade lagskolor fram. Laglärda tolkade den religiösa lagen (sharía) inom ramen för dessa skolbildningar. De troende kunde välja mellan olika 
laglärda för att få ett auktoritativt utlåtande. Fram till slutet av 1800-talet fanns ingen särskild familjerätt i Mellanöstern och Nordafrika och begreppet familj saknade juridisk relevans. Men sedan dess, och framför allt efter andra världskriget, har alltfler länder i denna region format statliga så kallade "lagar rörande den personliga statusen" som reglerar äktenskap, skilsmässa, vård av barn och arv. I stora delar av denna region uppfattar idag medborgarna detta rättsliga system som djupt historiskt förankrat och autentiskt muslimskt. Men i själva verket har familjerätten påverkats av europeisk familjerätt, inte minst de mer kvinnofientliga delarna av franska lagar. Historiskt har alltså muslimska familjerättsliga arrangemang varit flexibla, men idag har familjerättsliga arrangemang för många i Mellanöstern blivit den kanske allra viktigaste markören för en muslimsk identitet. Detta har stor betydelse för hur familjerättsliga reformer diskuteras i regionen och hur debatterna bland muslimska minoriteter i Europa utformas (se t.ex. Rabo 2005, 2007).

I länder som Syrien och Jordanien har staten med hjälp av sekulärt utbildade jurister och byråkrater monopol på att registrera äktenskap. Det duger inte längre att "gifta sig religiöst" med hjälp av en imam, eller att följa ättens egna traditioner. Äktenskapskontrakt skall undertecknas och arkiveras av statliga domstolar. I dessa länder - och många andra länder med en muslimsk majoritet - hanterar religiösa minoriteter som kristna och judar sina egna familjerättsliga angelägenheter. Staten har delegerat sitt monopol direkt till företrädare för olika minoritetssamfund. Alla kristna måste därmed gifta sig i sin egen kyrka som sedan ser till att äktenskapet blir statligt registrerat. Medan muslimer i princip kan gifta sig civilt utomlands och sedan få äktenskapet registrerat, är detta omöjligt för kristna. De måste gifta sig kyrkligt utomlands för att det egna samfundet - och i förlängningen staten - skall acceptera äktenskapet som juridiskt bindande. De kristna samfunden i Mellanöstern har alltså giftermålsmonopol.

\section{Vigselrätt}

I Sverige förlorade kyrkan detta monopol genom de - i ett europeiskt perspektiv radikala reformerna i början av 1900-talet. Från 1908 blev det möjligt att få borgerlig vigsel, men kyrklig vigsel var fortsatt rättsligt bindande. När den religiösa pluralismen ökade i Sverige kom fler och fler samfund att söka - och få - vigselrätt. De flesta så kallade frikyrkor har idag vigselrätt, liksom flertalet kyrkor som etablerats genom invandringen till Sverige sedan 1960-talet. I slutet av 1700-talet fick utländska katoliker begränsad möjlighet att utöva sin tro men först ett hundra år senare kunde svenska medborgare konvertera utan att riskera att tvingas lämna landet. Idag har runt fyrtio religiösa samfund - förutom Svenska kyrkan - vigselrätt och över tre tusen personer från dessa andra samfund har rätt att viga. Det finns till exempel trettiosex imamer som har vigselrätt. Företrädare för samfund som har vigselrätt är skyldiga att följa svensk lag, till exempel beträffande ålder på brudparet. Den 1 maj 2009 fick Sverige en ny könsneutral

Annika Rabo: Den goda familjen och den goda familjerätten. 
äktenskapslag. Sedan dess likställs Svenska kyrkan med andra samfund och har inte automatisk vigselrätt.

I många länder i Europa saknar religiös vigsel rättsliga följder. I Frankrike, Nederländerna och Belgien måste alla brudpar gifta sig borgerligt och en eventuell religiös ceremoni är en privatsak. I Spanien kan man välja mellan kyrklig eller borgerlig vigsel. I Norden har det inte funnits särskilt starka folkliga krav på avskaffandet av samfundens vigselrätt. Flertalet medborgare verkar anse att en kyrklig vigsel i våra länder inte är så särskilt religiös. Men på senare år har kraven på, och den allmänt ökade acceptansen för, könsneutrala äktenskap (samt de nya lagarna i Sverige och Norge) också fört med sig debatter om de religiösa samfundens juridiska roll (se Christoffersen 2006). ${ }^{4}$ Åsa Regnér, generalsekreterare i RFSU krävde i september 2008 att samfundens vigselrätt skall avskaffas. ${ }^{5}$ Svenska kyrkan valde i slutet av 2007 att behålla vigselrätten men i början av 2009 hävdade nio biskopar att detta numera är otidsenligt. ${ }^{6}$ Andra kyrkliga företrädare vill upphäva vigselrätten med hänvisning till att det kristna äktenskapet bör förbli ett förbund mellan en kvinna och en man. Frågan tycks dela Svenska kyrkan. Stockholms stifts nya biskop, Eva Brunne, menar att det nu är

4 I Norge trädde en ny könsneutral äktenskapslag i kraft den 1 januari 2009. I Danmark, Finland och Island finns än så länge bara möjligheter till registrerat partnerskap med lite olika innehåll.

5 Se www.svd.se/opinion/brannpunkt/artikel_1796829.svd

6 Se t.ex www.dagen.se/Article_Print.aspx? ID $=162623$ för sent att säga nej till vigselrätten. Det skulle idag "bli en olycklig sammanblandning mellan dem som i princip är emot samkönade äktenskap och därför vill att vi skall avsäga oss vigselrätten. Det är jag inte beredd till« (Solna församlingsblad 2009 nr 4).

\section{Samkönade äktenskapmen inte polygami}

I stora delar av världen har statliga myndigheter lättat på restriktionerna kring vilka som kan ingå äktenskap. Rätten att få gifta sig har i Europa stärkts på bekostnad av restriktioner som tidigare sågs som naturliga eller eftersträvansvärda (se t.ex. Harding 2008 s. 159 ff). ${ }^{7}$ Kyrkorättens inflytande i Europa har varit mycket stark och den förhindrade att människor som delade släktband eller band genom ingifte (eller nära samröre) fick gifta sig. Idag har de flesta länder bara kvar förbudet för äktenskap mellan syskon samt mellan barn och föräldrar. De senaste decenniernas mest radikala omvälvning i ett stort antal länder i Europa rör dock möjligheterna för samkönade äktenskap eller registrerat partnerskap. ${ }^{8}$ Men polygami är en äktenskapsform som lagstiftare i Europa inte vill acceptera. Inom ramen för den internationella privaträtten (se nedan) erkänner vis-

7 Däremot tycks restriktionerna beträffande ålder för äktenskaps ingående har stärkts. I Sverige kallas äktenskap mellan personer under 18 år rutinmässigt "barngifte».

8 Se t.ex. www.ilga-europe.org för information om denna utveckling 
serligen länder som Belgien, Storbritannien och Sverige - i princip - polygama äktenskap som ingåtts i länder där detta är tilllåtet. Men de accepterar inte att sådana utförs i det egna landet. Det må finnas faktiska former av polygamiliknande relationer genom olika typer av serieäktenskap eller informella samlevnadsformer (Swennen 2007 s. 136), men formellt flergifte uppfattas på de flesta håll i Europa strida mot den egna rättsordningen - ordre public - och skall inte uppmuntras. I offentliga debatter i länder som Frankrike, Nederländerna och Storbritannien framstår polygyna äktenskap - där alltså mannen har mer än en hustru - bland invandrade muslimer som ett stort och växande problem. John Bowen (2001 s. 18) menar dock att informella polygyna "äktenskap» bland "äkta» fransmän är betydligt vanligare. Men då dessa inte hotar den allmänna ordningen utan uppfattas som ett praktiskt och franskt sätt att praktisera familjeliv väcker de ingen anstöt. ${ }^{9}$

\section{Arrangerade äktenskap och tvångsäktenskap}

I ett historiskt och globalt perspektiv har arrangerade äktenskap varit - och fortfar att vara - vanligt förekommande. Sätten att arrangera tar sig, och har naturligtvis tagit sig, olika uttryck. I dagens Sverige tycks det bli allt vanligare att själv arrangera sökandet efter en partner. Olika dejting-fora på Internet kan sägas fungera som en sam-

9 En »fransk» konkubin har starkare rättslig position än en muslimsk andra-hustru i Frankrike enligt Bowen (2001 s. 18). tidens äktenskapsmäklare. I exempelvis Syrien arrangeras äktenskap - eller snarare möjligheten att hitta en fru eller make - på en mängd olika sätt. På landsbygden är ofta umgänget mellan kvinnor och män ganska informellt och unga träffas både $\mathrm{i}$ jordbruksarbetet och utanför. Men det är de äldre männen som sköter de ekonomiska förhandlingar som måste till för att de unga skall få gifta sig. I konservativa kretsar i syriska städer får unga giftaslystna män ofta hjälp av kvinnliga släktingar att hitta lämpliga kandidater. Mannen och släktingen går sedan på formellt besök hos den unga kvinnan. Många unga utbildade syrier träffar dock sin partner genom studier, på arbetsplatsen eller genom goda vänner och sköter förhandlingarna med familjerna på egen hand. Med andra ord hittar man i Syrien sin make eller maka på ganska olika sätt. Men utgångspunkten är att alla skall gifta sig. Att gifta sig - och att bli förälder är det naturliga sättet att bli vuxen.

Men var går gränsen mellan föräldrars, släktingars, vänners och grannars positiva hjälp att hitta en passande partner och att någon annan väljer en partner som man tvingas gifta sig med? I Storbritannien är denna fråga mycket livligt debatterad och i juli 2007 kom en ny lag mot tvångsäktenskap. ${ }^{10}$ Lagen syftar till att skydda personer från att bli gifta mot sin vilja och att skydda dem som redan blivit tvingade in i ett äktenskap. Forced Marriage Unit, en enhet inom inrikesministeriet som arbetar mot tvångsäktenskap, hanterar runt fyra

\footnotetext{
10 The Forced Marriage Act gäller i England, Wales och Nordirland men inte i Skottland.
} 
hundra fall per år, och de flesta rör personer med rötter i Pakistan eller Indien. Men många anser att dessa fall bara är toppen av ett isberg. ${ }^{11}$ I den brittiska debatten drar man en tydlig gräns mellan arrangerade äktenskap och tvångsäktenskap och det är alltså de senare som på olika sätt skall förhindras. Engelska muslimska organisationer har också engagerat sig i kampen mot tvångsäktenskap.

2003 fick Norge en ny äktenskapslag där brud och brudgum på heder och ära skall deklarera att de gifter sig av fri vilja. Denna nya lag var framförallt inriktad på att ge muslimska kvinnor i Norge lika rätt som sina män till skilsmässa. I dagens Mellanöstern är debatterna livliga för hur staterna och samhällena skall balansera internationella och inhemska krav på kvinnors och mäns lika rätt inför lagen och kraven från den religiösa lagen där kvinnor och män är lika inför gud men har olika rättigheter och skyldigheter i samhället. I klassisk islamisk rätt är det männen som har oförbehållsam rätt att skilja sig medan kvinnor kan få äktenskapet upplöst på olika juridiska vägar.

Norge och de övriga nordiska länderna var mycket tidigt ute med att göra det möjligt att skilja sig om båda parter så önskade. Det nordiska samarbetet på familjerättens

$11 \mathrm{Se}$ exempelvis www.familylawweek.co.uk/ site.aspx?i=ed24572 . I Svenska Dagbladet 2.8 2009 diskuteras den engelska lagen under rubriken Krafttag mot tvångsäktenskap. Artikeln nämner också en ny svensk rapport från Ungdomsstyrelsen som förespråkar kriminalisering av tvångsäktenskap. Se www.ungdomsstyrelsen.se/art/0,2072,7770,00.html område som inletts från mitten av 1800talet intensifierades under 1900-talets början och den första stora frågan gällde villkoren för äktenskapets upplösning. Medan de flesta andra europeiska länder och USA först på 1970-talet accepterade skilsmässor utan att någon av parterna skulle anses som skyldig till äktenskapets misslyckande tillkom denna (»ingens fel») princip i nordisk rätt redan på 1920-talet (Melby et al. 2006 s. 113). Men fortfarande har många EU-länder en lagstiftning där skilsmässa bara kan erhållas genom att skylla på någon av parterna. Enda skälet till att få skilsmässa i England eller Wales är att äktenskapet inte går att rädda och detta måste kunna visas genom exempelvis bevis på en av parternas otrohet. ${ }^{12}$

2003 års norska lag innebär att alla som gifter sig i Norge måste underteckna en deklaration där de wanerkjenner at min fremtidige ektefelle har lik rett til skilsmisse som meg" (Thorbjörnsrud 2005 s. 17). ${ }^{13}$ Lagen kan ses som en förlängning av den nordiska jämställda hållningen där kvinnor och män har lika rättigheter och skyldigheter inom äktenskapet och den antogs rekordsnabbt av Stortinget utan vanlig remissomgång. I Norge var det organisationen Human Rights Services som bedrev lobbyverksamhet. Deras bok Feminin integrering påstod att så kallade haltande äktenskap (där paret är skilda civilt men inte religiöst, eller tvärtom, eller där

12 För information om lagar rörande skilsmässor inom EU se http://ec.europa.eu/civiljustice/ divorce/divorce_ec_en.htm

13 Denna deklaration hanteras av norska Folkeregisteret. 
en skilsmässa från ett land inte erkänns i ett annat) var ett mycket allvarligt problem för muslimska kvinnor i Norge. Organisationen ansåg att en ändring av lagtexten enkelt skulle avhjälpa detta och krävde också att alla som ansökte om familjeåterförening skulle skriva på ett papper om båda parters lika rätt till civil och religiös skilsmässa (Waerstad 2006 s. 4-5). ${ }^{14}$

Lagförslaget var alltså direkt ämnat att skydda utsatta muslimska kvinnor men i debatterna om den norska lagen var det i själva verket kristna och judar som var mest aktiva. För troende katoliker, exempelvis, är äktenskapet ett sakrament där enbart döden skiljer makarna åt. Kyrkan accepterar inte skilsmässa och viger inte personer som skilt sig civilt. Katolska kyrkan i Norge gjorde snabbt en egen blankett där de som skall vigas i kyrkan deklarerar att den norska civila blanketten inte gäller deras eget äktenskapslöfte. ${ }^{15}$ Påven hörde också av sig till den norska regeringen och protesterade mot lagen som ansågs strida mot den norska religionsfriheten (Christoffersen 2006 s. 116). Norska Stortingets ledamöter, menar Berit Thorbjörnsrud (2005 s. 17), hade inte klart för sig att andra än muslimer skulle drabbas av den nya lagen. De var helt enkelt inte medvetna om den familjerättsliga pluralism som faktiskt rådde i landet. Stortingets ledamöter verkade inte heller på det klara med att medan skilsmässa är tillå-

14 Detta senare förslag som rörde ändring av utlänningslagen accepterades inte då det ansågs stå i strid mot de internationella konventioner Norge undertecknat (Waerstad 2006 s.6).

15 Se www.katolsk.no/nyheter/special/blankett-c. htm tet i alla länder med en muslimsk majoritet är så inte fallet i alla länder med en kristen majoritet. På Malta - medlem i EU - kan ingen få skilsmässa och om ett par från Cypern gifter sig i den grekisk ortodoxa kyrkan kan de inte bli skilda utan att kyrkan ger sitt medgivande.

Den cypriotiska situationen liknar den vi finner för kristna i flertalet länder i Mellanöstern. Ett par som gift sig i kyrkan kan inte upplösa sitt äktenskap annat än genom en kyrklig dom. I Syrien, som nämnts tidigare, har staten delegerat vigselrätten för kristna till de olika kyrkorna, och det är omöjligt för kristna par att skilja sig i en statlig shari'a domstol. De måste vända sig till särskilda kyrkliga domstolar som domineras av präster. För katoliker är skilsmässa inte alls tillåtet men äktenskapet kan i vissa fall annulleras. De olika ortodoxa samfunden ger skilsmässa men bara på grund av specifika skäl. Att paret själva vill räcker inte. För ett syriskt muslimsk par som bestämt sig för att skiljas är proceduren ganska enkel och snabb, men för ett kristet par kan det vara mer eller mindre omöjligt. Om ett kristet par migrerat till exempelvis Norge och skilt sig där erkänner inte den syriska staten skilsmässan. Paret lever då i ett haltande äktenskap och vare sig kvinnan eller mannen kan gifta om sig och få det nya äktenskapet erkänt i Syrien om de inte först får en kyrklig skilsmässa i Norge eller i hemlandet. Ett muslimskt par som skiljer sig i Norge kan utan problem få skilsmässan erkänd i Syrien. ${ }^{16}$ Samma typ av minoritets-

16 Men om paret inte är överens om att skiljas kan det bli mer komplicerat. Skilsmässan kan då anses strida mot syrisk ordre public.

Annika Rabo: Den goda familjen och den goda familjerätten. 
lagstiftning och rättspluralism finns i Iraq och Jordanien. I Libanon och Israel finns inga statliga domstolar eller lagstiftning som hanterar giftermål och skilsmässa utan judar, muslimer, kristna och druser följer reglerna från respektive samfund. Haltande äktenskap är ett allvarligt problem för judiska kvinnor i Israel och för judiska ortodoxa kvinnor i andra länder (se t.ex. Blecher-Prigat \& Shmueli 2009). Judiska män har-liksom muslimska - exklusiv rätt till skilsmässa, men till skillnad från muslimska kvinnor har judiska kvinnor färre rättsliga instrument till sitt förfogande för att få en skilsmässa mot mannens vilja. ${ }^{17}$ Det måste också understrykas att haltande äktenskap inte är ett nytt utan ett välkänt juridiskt problem mellan länder i Europa. Länder där medborgare haft begränsad möjlighet att skiljas har inte velat erkänna en skilsmässa genomförd i ett land med mer liberal lagstiftning (McGlynn 2006 s.156).

Flera organisationer kom senare att kritisera den nya norska lagen, inte minst för dess syn på muslimer. KIM, en organisation med inriktning på kontakt mellan invandrare och myndigheter menade att muslimska kvinnors eventuella problem med haltande äktenskap inte kan lösas lagvägen, utan kräver andra lösningar i samarbete med de norska muslimerna. Tone Linn Waerstad, som gjort en rättsantropologisk studie av skilda muslimska kvinnor i Norge, menar att det saknades ordentlig kunskap i ämnet när lagen antogs. Hon djupintervjuade tio skilda muslimska kvinnor som

17 För ett intressant fall där en israelisk judisk kvinna fick vänta 18 år på att bli skild se www. international-divorce.com/d-israel.htm alla hade haft våldsamma konflikter i sina äktenskap och i flertalet fall också i samband med skilsmässorna. Men kvinnorna ansåg inte att deras religiösa tillhörighet var ett hinder för att söka en vanlig norsk civil skilsmässa (Waerstad 2006 s. 82). Flertalet av dessa kvinnor hade också fått stöd av sina familjer i sina beslut. Men i vissa fall hade kvinnorna svårt att bli socialt accepterade i Norge som skilda. Waerstad (2006 s. 84) understryker att de religiösa muslimska miljöerna inte är homogena och att det finns många olika sätt att tolka islam $\mathrm{i}$ Norge idag.

\section{Sharia-domstolar}

Diskussioner om muslimers eventuella haltande äktenskap har förts på olika håll i Europa. I England har dessa diskussioner ofta varit kopplade till frågan om wislamisk rättı skall erkännas i Storbritannien och om sharia-domstolar redan finns i landet. I februari 2008 höll Ärkebiskopen av Canterbury, Dr Rowan Williams, ett föredrag där han diskuterade religiösa gruppers rättigheter i sekulära stater. Han underströk att han inte argumenterade för parallella system där exempelvis brittiska muslimer enbart skulle finnas i ett slags muslimskt lagrum, men många uppfattade att det var just så han sa. Den massmediala debatten lät inte vänta på sig. Många var upprörda över - som de såg det - islams frammarsch i England. Denis MacEoin (2009) gjorde en egen inventering och påstod att det finns åtminstone 85 sharia-domstolar i England som opererar utanför den brittiska lagen och att många fall i dessa domstolar rör 
skilsmässa och vård av barn. Andra debattörer menade dock att sådana siffror var gripna ur luften och att begreppet shariadomstol är missvisande. De finns ett antal så kallade sharia councils i England som hjälper muslimer att på frivillig väg lösa konflikter utanför domstolssystemet och detta är fullt lagligt. ${ }^{18}$ Dessa rådgivande organisationer har, exempelvis, inte rätt att upplösa äktenskap.

Också i Nederländerna har frågan om sharia-domstolar debatterats, bland annat i NRC Handelsblad i juli 2009. Maurits Berger, professor i islamisk historia, understryker att det inte finns sharia-domstolar i landet, men att det redan finns parallella rättsliga system. Det finns domstolar som tillämpar lagen och det finns olika organisationer som medlar i konflikter och dit folk vänder sig för att lösa problem och tvister. Judiska och katolska församlingar har vidare egna religiösa "domstolar" som "dömer" med utgångspunkt från religiös rätt. Berger menar att det skulle vara svårt att neka muslimer det som är accepterat för katoliker och judar. Det betyder inte att de religiösa domstolarna ersätter statens lag eller att staten tar hänsyn till domslut i dessa religiösa domstolar.

Det är ingen tvekan om att rädslan för "shariau är utbredd i Europa. Men det finns bara ett enda land - Grekland - där shariadomstolar faktiskt existerar inom ramen för det statliga rättsystemet. I en överenskommelse från 1881 mellan Grekland och det tidigare osmanska imperiet utlovades

18 Denna debatt kan exempelvis följas i tidningen the Guardian. Sök via /www.guardian.co.uk/ och skriv sen in sharia councils. att grekiska muslimer skulle få följa islam beträffande sin personliga status (giftermål, skilsmässa, vård av barn). Denna överenskommelse gäller än idag för de cirka 100000 muslimer som bor i västra Trakien (Tsaoussi \& Zervogianni 2008). Medan Turkiet 1926 helt tog bort sharia- och kristna domstolar ur sitt rättssystem, har alltså Grekland kvar detta utrymme. Muslimer i Turkiet kan alltså inte gifta sig religiöst och få detta erkänt av staten, medan detta är möjligt för trakiska muslimer i EU-landet Grekland. Aspasia Tsaoussi och Elena Zervogianni är kritiska till denna minoritetsinstitution och menar att den förstärker den regionala trakiska muslimska subkulturen. De menar att kvinnor och barn riskerar att missgynnas i sharia-domstolarna (2008 s. 217). De föreslår att Grekland istället borde bygga ut ett system av familjemedlare som kan verka på ett både rättvist och kulturellt känsligt sätt. De förordar med andra ord ett system liknande det $\mathrm{i}$ England med sharia councils som har ett informellt medlingsmandat.

\section{Barn}

Att barn inte är en förlängning av sina föräldrar utan har egna rättigheter $i$ enlighet med Barnkonventionen, är något som listas på den norska hemsidan. Men att agera för barnens bästa kan bli problematiskt när vuxna har olika åsikter om vad detta är. Lucy Smith, pensionerad professor i juridik från Oslo universitet, skriver att det är slående att barns rättigheter numera erkänns i nationella och internationella sammanhang. Även om verkligenheten inte alltid följer dessa 
idéer, regler, lagar och konventioner, så har mycket hänt (Smith 2008 s. 53). Men barns rättigheter, och barnets bästa kan gå på tvärs mot föräldrarnas. Hur skall vårdnadstvister lösas när föräldrar blir allt rörligare?

I USA flyttar runt 40 miljoner människor varje år. Nästan sex miljoner flyttar över en statsgräns och runt en och en halv miljon flyttar till ett annat land (Glennon 2009 s. 84). Kvinnor och män flyttar i samma utsträckning i USA, men det är en kvinnlig majoritet som får vårdnaden av barn vid skilsmässa. Därför är det framför allt kvinnor som måste söka domstolens tillstånd för att få flytta. Trots den ökade rörligheten bland föräldrar och trots att problemen med tvister runt detta menar Theresa Glennon (2009) att domstolarna saknar gemensam policy hur dessa skall hanteras. Delad vårdnad och gemensamt föräldraansvar börjar växa fram som en modell på många håll i Europa. Detta ses ofta som bra både för barn och för de vuxna, men Anna Singer är kritisk till att svenska domstolar ibland dömer till delad vårdnad trots att föräldrarna inte alls kommer överens. Vi vet alldeles för litet om hur barn mår av detta, menar hon (2009 s. 71). Vårdnadstvister är naturligtvis svåra var och när de än förekommer, men internationella tvister är särskilt problematiska eftersom lagar och praxis från olika länder kan komma i konflikt.

1980 tillkom Haagkonventionen för att lösa internationella vårdnadstvister men det är många länder som inte undertecknat den. ${ }^{19}$ I de flesta länder i Mel-

19 För mer information om se http://www.hcch. net/index_en.php?act=text.display\&tid=21 lanöstern uppfattas konventionen strida mot den egna lagstiftningen och rättsuppfattningen. Det finns en rättslig ordning om mamman och pappan har samma medborgarskap och en annan om den ena är utlänning. Om modern och fadern har olika nationalitet är det faderns som gäller vid konflikter som rör föräldraskap. I de allra flesta länder i regionen kan inte kvinnor som gift sig med en utlänning ge sitt medborgarskap till sina egna barn. ${ }^{20}$ Det betyder att i exempelvis jordansk lag är det inte bara parets hemvist - deras domicil (se nedan) - som gäller när en vårdnadstvist skall avgöras, utan faderns ursprungliga medborgarskap gör att hans barn kommer att betraktas som jordanska. I exempelvis tunisisk och marockansk lag förlorar en inhemsk mamma rätten att vara vårdnadshavare om hon flyttar långt från pappan. I Syrien får den syriska modern flytta med barnet men bara om hon arbetar inom offentlig tjänst och flyttar för arbetes skull eller om hon flyttar tillbaka till den stad där hon har nära familjemedlemmar. Men enligt syrisk lag får inte heller pappan resa med barnen utan den syriska moderns tillstånd så länge som hon är vårdnadshavare (Nasir 2009 s. 198-199). Vid skilsmässa är modern i regel vårdnadshavare tills barnen når puberteten. Om däremot en utländsk kvinna i Syrien vill ta de barn hon fått med en syrisk man till sitt hemland har hon inte rätten på sin sida. Men om det motsatta

20 Egypten och Marocko har ändrat sin medborgarskapslag 2004 respektive 2007. Barn till kvinnor gifta med utlänningar kan nu få moderns medborgarskap. Sverige ändrade sin lag 1979 . 
händer har fadern oftast syrisk rätt på sin sida (Rabo kommande).

Trots att många länder inte skrivit under Haagkonventionen kan internationella vårdnadstvister lösas genom bilaterala avtal. Sverige och Egypten har exempelvis undertecknat ett sådant rörande samarbete i civilrättsliga frågor. Avtalet tar upp att just vårdnadstvister om möjligt skall göras upp i godo mellan de båda länderna. Det är också viktigt att understryka att i väldigt många fall av potentiella internationella vårdnadstvister löser föräldrarna själva frågan om barnens boende. I de flesta fall jag känner till vill pappor från Mellanöstern att deras barn skall ha möjlighet till utbildning och arbete i Europa, Australien eller USA, även om det betyder att de förlorar den dagliga kontakten med dem.

Internationella kidnappningsfall där en förälder mot den andras vilja tar barn från ett land till ett annat tycks ändå vara ett växande problem. Fall blir ofta belysta $\mathrm{i}$ massmedia och "varje lands medier har en tendens att mest uppmärksamma sina egna medborgares våndor" skriver Per Binkemo i en artikel i Svenska Dagbladet( 27.1. 2003. jmf Rabo 2007 s. 160). Vi har en tendens att sympatisera med svenska medborgare - särskilt mammor - som förlorar sina barn till utlandet. Men det är nästan lika många fall där svenska medborgare olovligen för barn till Sverige, inte minst från USA, och idag är det mest mammor som tar barn från ett land till ett annat, skriver han.

\section{Blodsband och andraband}

Att faderns nationalitet väger högre än moderns i de flesta länder i Mellanöstern är ett utslag av jus sanguinis-blodsrätten och en lång tradition av patrilinjär härstamning. I den klassiska islamiska juridiken accepteras inte adoption och detta gäller fortfarande i flertalet länder i Mellanöstern. Barns rätt till kunskap om sitt ursprung - en av artiklarna i Barnkonventionen är något som alltid understryks i dessa länder. Idéer om blodsband och härstamning har varit synnerligen betydelsefulla $\mathrm{i}$ nationalistiska rörelser och fortfarande är jus sanguinis den vanligaste principen för att erhålla medborgarskap runt omkring i världen. I viktiga invandrarnationer som USA, Kanada och Australien är det istället jus soli-territorialprincipen som gäller. Den som föds inom landet blir automatiskt medborgare. I Europa är det bara Frankrike som traditionellt tillämpat denna princip. Det har historiskt varit enklare att bli medborgare genom naturalisation i länder med en stark tradition av jus soli.

Tyskland är exempel på ett land med mycket starka idéer om blodsband och där det varit ytterst svårt för invandrare att bli medborgare. Detta har viktiga familjerättsliga konsekvenser för alla de som är födda i landet men som inte är tyskar, utan som omfattas av sina "hemländers" lagar. Men också i Frankrike har den radikala territorialprincipen fått stryka på foten och det har blivit svårare för vissa kategorier av invandrare att få franskt medborgarskap. I vissa länder i Europa - som Sverige - har det de senaste decennierna, däremot, blivit enklare att få medborgarskap. Sverige hör också till de länder som (sedan 2001) accepterar dubbla medborgarskap. Detta underlättar naturligtvis rörlighet och integrering för

Annika Rabo: Den goda familjen och den goda familjerätten. 
många invandrare/utvandrare. Men samtidigt gör det att exempelvis internationella vårdnadstvister kan bli ännu mer komplicerade om barn (och föräldrar) har flera hemländer och om domstolarna inte kan enas om hur motstridiga lagar skall tolkas.

"Blodsband" och »härstamning» är alltså fortsatt viktiga principer för nationell tillhörighet. De är också fortsatt mycket viktiga i familjeanknytningsfall. Inom Europeiska Unionen har barn under 18 år i princip rätt att bli återförenade med sina föräldrar. $^{21}$ I Sverige är DNA-tester ett sätt att försäkra sig om att banden mellan barn och förälder/föräldrar verkligen är »äkta». Samtidigt blir dessa band allt mindre viktiga när det gäller olika typer av nya familjebildningar i Sverige och västvärlden generellt. Nya reproduktiva tekniker och genteknik har öppnat för helt nya typer av föräldraskap och barnalstrande vilket också får konsekvenser när människors rörlighet ökar. Lucy Smith (2008 s. 61-62) understryker att dessa nya tekniker kräver ny lagstiftning så att barnens bästa kommer i förgrunden. Olika typer av kontrakt mellan personer med olika roll i det reproduktiva och det sociala föräldraskapet håller på att växa fram (se t.ex. Maxwell 2009, Scharma 2009, Vonk 2009). Allt detta sammantaget ropar också på internationellt samarbete då många vuxna som vill använda sig av nya reproduktiva tekniker gör det i länder där detta erbjuds. Om ett ägg doneras av en tysk kvinna, sperma av en dansk man, och fostret bärs av en kvinna i USA men

21 Denna principiella rätt är dock omgärdad med en stor mängd nationella undantag (McGlynn 2006 s. 54 ff). uppfostras av ett par i Nederländerna blir det minst sagt komplicerat om det uppstår konflikter kring föräldraskapet. Här står den internationella privaträtten inför stora utmaningar.

\section{Internationell privaträtt, domicilprincipen och EU}

Internationell privaträtt är den gren av juridiken som »reglerar privaträttsliga förhållanden som har anknytning till fler än en stat" (Jänterä-Jareborg 1997 s. 21). Tre frågor är av vikt. Är domstolen i landet behörig att hantera ärendet? Vilket lands lag är det som gäller i ärendet? Gäller utländsk dom i landet? Avtal mellan personer (eller företag) med hemvist i olika länder är ett stort fält för den internationella privaträtten. Familjerätten är en annan viktig del. Flera frågor som diskuterats i denna artikel - polygami, "haltande äktenskap« och internationella vårdnadstvister - har direkt koppling till den internationella privaträtten. Det finns olika sätt att hantera frågor om den internationella privaträtten. Den så kallade Haagkonferensen är ett av dem. Redan 1893 genomfördes det första mötet för att ena och samordna den juridiska utvecklingen i detta fält och 1951 gjordes konferensen till en permanent internationell organisation med säte i Haag. De länder som ansluter sig deltar i förhandlingar rörande olika internationella konventioner. Andra sätt är, som nämnts ovan, genom avtal mellan två stater.

Syrien, exempelvis, är inte medlem i Haagkonferensen men brukar regelmässigt, som diskuterats ovan, erkänna äktenskap 
som är ingångna utomlands så länge dessa inte strider mot syrisk ordre public - den allmänna rättsuppfattningen. Samkönade äktenskap erkänns dock inte i Syrien (eller i majoriteten av länder i världen). Inte heller erkänns äktenskap mellan en muslimsk kvinna och en icke-muslimsk man.

"Norsk lag gäller för alla som bor i Norge" står det på listan på den norska hemsidan. Detta kan låta som en slogan från någon främlingsfientlig grupp, men är i själva verket en vanlig juridisk princip. Domicilprincipen betyder att personer som stadigvarande bor i ett land skall följa dess lagar. Tidigare var nationalitetsprincipen stark. En person med utländskt medborgarskap skulle i Sverige i exempelvis ett mål om skilsmässa dömas efter sitt hemlands lagar. Detta ansågs i Sverige mer och mer opraktiskt ju fler personer som flyttade till och bosatte sig här. Allt fler personer blev också medborgare, eller kom att bilda familj med svenska medborgare och kom att ha starkast anknytning till Sverige.

En annan anledning till att hemvistprincipen blev allt starkare var att svensk (och nordisk) familjerätt under lång tid, som diskuterats ovan, skilde sig från familjerätt i många andra länder. En svensk medborgare som gift sig med en fransk medborgare och som bodde i Sverige kunde exempelvis ha mycket svårt att få skilsmässa om fransk lag skulle följas för den franska partnern. Domicilprincipen kom alltså i konflikt med internationella överenskommelser, inte minst den konvention av Haagkonferensen som reglerade skilsmässa. Den tidiga Haagkonferensen baserade sina överenskommelser på nationalitetsprincipen medan domicilprincipen vunnit starkare kraft de senaste decennierna. Maarit Jänterä-Jareborg (1997 s. 44-45) ser flera anledningar till detta. Ökade antal dubbla medborgarskap gör nationalitetsprincipen svår att hantera. Vilket medborgarskap är det som skall räknas? Domstolarna måste också vara kompetenta att döma i enlighet med utländsk rätt, vilket kräver stor kunskap. Vidare brukar personer som bosätter sig i ett nytt land anpassa sig till det nya landets lagar men ha svårt att hålla reda på vad som gäller i inemlandet".

Men domicilprincipen gäller inte överallt. Tyskland tillämpar nationalitetsprincipen. Trots att Tyskland 2001 gjorde det enklare för utlänningar att erhålla medborgarskap är det fortfarande mycket svårt och runt nio procent av befolkningen lyder $\mathrm{i}$ princip under sina "hemländers" familjerätt. Det finns exempelvis 1.7 miljoner turkar i Tyskland där många av dem är födda $i$ landet. Familjerätten mellan Tyskland och Turkiet skiljer sig inte så mycket åt så dessa ärenden är inte så komplicerade för tyska domstolar. Redan 1926 tog Turkiet, som diskuterats ovan, bort både islam och de kristna samfundens roll i familjerätten. För invandrare från Marocko eller Syrien som skall följa sina hemländers rätt beträffande giftermål och skilsmässa, även om de bor permanent i Tyskland, kan dock situationen bli mer komplicerad och konfliktfylld. Men domicilprincipen börjar få genomslag också i Tyskland. Ett syriskt kristet par som varit bosatta många år i Tyskland kom överens om att skiljas där. Den lokala domstolen ville först inte gå med på detta då kristna syrier, som diskuterats ovan, enbart kan upplösa sina äktenskap genom en kyrklig dom. Paret överklagade och underströk att de var

Annika Rabo: Den goda familjen och den goda familjerätten. 
permanent bosatta i Tyskland. En federal domstol gav paret rätt att skiljas med hänvisning till Tysklands ordre public. Domaren menade att denna måste tolkas i ljuset av den förändrade sociala och juridiska miljön i landet där också utvecklingen $i$ andra länder bör tas med i beaktande. Därmed tycks den tyska förståelsen av ordre public ha påverkats av ett större europeiskt sammanhang. ${ }^{22}$

Den Europeiska Unionen har en tydlig ambition att lagstiftning, inklusive familjerätten, skall harmoniseras för att inte hindra ökad rörlighet. Samtidigt skall rörligheten för medborgare utanför unionen kontrolleras och begränsas. Men reglerna inom EU för att få medborgarskap och permanent uppehållstillstånd skiftar avsevärt från land till land och det är fortfarande oklart hur personer som inte är medborgare eller permanent boende i ett EU-land skall hanteras inom familjerätten. Det finns alltså en mängd potentiella krockar inom det familjättsliga området som aktualiseras genom migration, ökad rörlighet och familjeband som sträcker sig över nationella gränser. Inte ens inom EU är de nationella lagstiftningarna, som diskuterats ovan, harmoniserade.

Vissa jurister och debattörer är synnerligen positivt inställda till harmonisering av familjerätten inom EU, men andra är mer skeptiska. Den nederländska juristen Ted de Boer (2008 s. 322) påpekar att den överstatliga EU-lagstiftningen ger ökad möjlighet för medborgare att välja domstolsland,

22 http://www.internationalfamilylawfirm. com/2007/11/german-divorce-syrian-marriage.htm och välja vilken nationell lag som skall gälla i ett mål. Men ingen kan begära att ett par med olika medborgarskap som flyttar inom EU i förväg borde fundera över var och hur de bäst kan ordna en skilsmässa. Han påpekar också att olika medlemsstater fortfarande har mycket olika syn på skilsmässa (se ovan). Äktenskapet fortsätter att vara en mycket viktig samhällelig institution och medlemsstaterna verkar inte övertygade om att skilsmässa är en privat angelägenhet som bara rör paret (de Boer 2008 s. 335).

Det finns harmoniseringsskeptiker som menar att EUs försök att skapa enhetlighet och sammanhållning exkluderar mer radikala och alternativa sätt att se på familj och rätt. Det blir mindre pluralism och mindre beredskap att hantera en mångfacetterad verklighet, menar Clare McGlynn (2006 s. 191). Andra menar att familjerätten är så inbäddad i en nationell kultur att den inte kan harmoniseras med andra länders. Masha Antokolskaia $(2007,2009)$ visar dock att så inte är fallet i Europa. Under vissa perioder har familjerätten konvergerat och under andra blivit mer olika. Före den protestantiska reformationen var den mer enhetlig än efter; en process som intensifierades fram till början av 1800-talet. Sen kom en period av nationella rörelser och divergerad familjerätt men efter 1960-talet har familjerätten åter börjat konvergera igen (Antokolskaia 2007 s. 13-16). Familjerätt och familjepolitik blir mer likartade i Europa och lagstiftningen harmoniseras i många frågor. Det råder till exempel stor enhetlighet i lagar rörande makars likhet inför lagen samt likhet för barn som är födda inom eller utanför äktenskapet (Antokolskaia 2009 s. 49). 


\section{Rätten till likhet och till olikhet}

Vi blir alltså mer och mer familjerättsligt reglerade både nationellt, överstatligt och internationellt. Detta kan ställa till särskilda problem för migranter eller medborgare med ursprung utanför Europa och EU, särskilt för de som upprätthåller starka band med sina "hemländer". I denna artikel har jag pekat på några familjerättsliga krockar där de inblandade personerna med rötter i Mellanöstern önskar en sak men där nationell lagstiftning säger något annat. Ett kristet par från Syrien, Libanon, Jordanien eller Israel som bor i Sverige och genomför en skilsmässa här får inte denna erkänd i sitt "hemland». De kan därmed inte gifta om sig med någon från Mellanöstern utan att deras religiösa domstol upplöser det tidigare äktenskapet. Så länge detta inte sker är de inte skilda i lagens mening utan lever alltså i ett haltande äktenskap. Andra potentiella krockar mellan lagstiftning i Mellanöstern och Sverige rör adoption som inte erkänns i lagstiftningen i Mellanöstern. Ett par (eller en enskild person) som adopterar ett barn i Sverige och som vill registrera detta i "hemlandet" kan få problem. Vårdnadstvister över gränser är särskilt plågsamma för alla inblandade, inte minst barnen. I Mellanöstern är i princip fadern alltid barnens förmyndare och modern är bara "omhändertagare« tills de når en viss ålder (som är olika i olika länder). Här krockar alltså själva begreppet vårdnadshavare. Arv ligger visserligen något utanför klassisk familjerätt (men är i Mellanöstern en del av lagstiftningen runt de så kallade personliga statusen, se ovan) men är ett område med potentiella krockar. I Mellanöstern ärver inte personer med olika religion varandra. En muslimsk man från Jordanien som skaffat familj i Sverige kan inte låta fru och barn ärva i Jordanien om de inte är muslimer. Och enligt den jordanska lagen ärver hustru och döttrar mindre än söner, vilket inte är fallet i Sverige. I Mellanöstern kan dock en mängd familjerättsliga krockar hanteras med myndigheternas goda minne. Adopterade barn kan registreras och vårdnadstvister över gränser kan lösas med hänvisning till internationella avtal, som diskuterats ovan. Arvsfrågor kan lösas genom förtida arv. Men en familjerättslig krock verkar oöverstiglig. Inget land i Mellanöstern accepterar att registrera ett äktenskap mellan en muslimsk kvinna och en icke-muslimsk man. Mannen måste först konvertera.

Samtidigt som den familjerättsliga regleringen intensifieras nationellt överstatligt och internationellt ökar dock möjligheterna att informellt välja ett visst slags familjeliv för de som ses som delaktiga i den europeiska, så kallade, värdegemenskapen. Också i denna process stöter migranter eller medborgare med ursprung utanför Europa och $\mathrm{EU}$ på särskilda problem. Om dessa gränskorsare inte visar att de omfamnar den ideala europeiska familjen - i dess olika nationella versioner - riskerar de att bli utpekade som hot mot den moraliska ordningen.

Den norska listan både pekar på och skapar ett sådant hot. Men är inte listan rimlig? Är det inte rätt och riktigt att lyfta fram centrala familjerättsliga värden? På ett plan är det naturligtvis rimligt att lista vad

Annika Rabo: Den goda familjen och den goda familjerätten. 
norska lagen föreskriver. Men samtidigt är det inte rimligt att skriva fram en moralisk ordning som om den vore nationellt unik. Anja Bredal (2005) och Anniken Hagelund (2008) understryker att i Danmark, Norge och Sverige generaliseras muslimska kvinnors problem med haltande eller tvångsäktenskap och "hedersvåld» utifrån enskilda och sällsynta fall. Kanske görs detta för att upprätthålla bilden av att vår jämställdhet är bäst i världen, men argumenten används också för att reglera invandringen och kontrollera invandrare. Listans och lagarnas verkningsgrad kan också ifrågasättas. Anne Phillips (2007 s.120) noterar att bara ett enda fall av tvångsäktenskap kommit till norsk domstol sedan lagen infördes. Att stifta lagar på svaga underlag gör att deras symboliska snarare än deras rättsliga verkan dominerar.

Ger lagar uttryck för medborgarnas moral och normer, eller påverkar de medborgarnas normer, moral och sociala praktik? Jag menar att det handlar om både och. Det finns en ömsesidig påverkan mellan det medborgare uppfattar som rätt, det folk gör och det lagen föreskriver, samt hur lagen tolkas av jurister och rättslärda. Detta både och märks särskilt tydligt när det gäller familjerättsliga frågor. Exempelvis har begrepp som barnet $i$ centrum påverkat svensk lagstiftning och policy som i sin tur påverkat medborgarna i Sverige. Debatterna runt samkönade äktenskap visar också på denna växelverkan. Familjerättsliga frågor är därför särskilt intressanta att analysera för att de sätter fingret på grundläggande relationsfrågor: Vad är en familj? Hur skall relationer mellan barn och föräldrar regleras? Vilka skyldigheter och rättigheter har gifta eller sammanboende mot varandra? Men familjerättsliga frågor är också intressanta för att de talar till och säger något om djupa och viktiga moraliska frågor som rör samhället i stort. En sådan viktig fråga rör likhet inför lagen. Hur olikt får vi ordna våra familjeförhållanden? Hur olika får villkoren för ett normalt familjeliv se ut i exempelvis dagens Sverige eller inom den Europeiska Unionen? Vilka möjligheter bör vi ha att leva våra liv precis som vi vill? Vilka rättmätiga krav kan staten eller den Europeiska Unionen ställa på våra familjearrangemang? Vad är den goda familjen och den goda familjerätten? Är harmonisering av lagstiftningen - som EU strävar till idag - alltid att föredra eller säkerställer olikheter i nationella lagar att hänsyn tas till kulturella och historiska särdrag? Har etniska eller religiösa minoriteter rätt att kräva särlagstiftning? Är olikhet inför lagen ett sätt att skydda just minoriteters rättigheter? (jmf Shachar 2001).

Detta är svåra frågor som saknar givna och enkla svar. Stat och medborgare kan ha olika intressen och se olika på den goda och den normala familjen. Lagen bör stötta den part som har svårare att komma till tals på grund av ålder, kön eller rikedom och makt. Men alla familjeproblem kan inte lösas med lagar. Socialt erkännande bland nära och kära kan inte tvingas fram via lagstiftning. Lagar kan inte heller ersätta det offentliga samtalet (Banakar 1994 s. 301). Det mångkulturella Europa ropar idag efter samtal där deltagarna inte på förhand vet att de har rätt eller rätten på sin sida. 


\section{Referenser}

Antokolskaia, Masha (2007) "Harmonisation of family law in Europe. A historical perspective». In M. Antokolskaia (ed.) Convergence and Divergence of Family Law in Europe. Antwerpen: Intersentia.

Antokolskaia, Masha (2009) „Family law and national culture. Arguing against the cultural constraints argument". In K. Boele-Woelki (ed.) Debates in Family Law around the Globe at the Dawn of the $21^{\text {st }}$ Century. Antwerpen: Intersentia.

Banakar, Reza (1994) Rättens dilemma. Om konflikthantering $i$ ett mångkulturellt samhälle. Lund: Bokbox Förlag.

Blecher-Prigat, Ayelet \& Shmueli, Benjamin (2009) »The interplay between tort law and religious family law. The Israeli case». Arizona Journal of International \& Comparative Law, vol 26, no 2, pp. 279-301.

De Boer, Ted M. (2008) »The second revision of the Brussels II regulation. Jurisdiction and applicable law». In K. Boele-Woelki \& T. Svendrup (eds.) European Challenges in Contemporary Family Law. Antwerp: Intersentia.

Bowen, John R. (2001) Shari'a, State, and Social Norms in France and Indonesia. Leiden: ISIM

Bredal, Anja (2005) "Tackling forced marriages in the Nordic countries. Between women's rights and immigration control«. In L. Welchman \& S. Hossain (eds.) "Honour" Crimes, Paradigms, and Violence against Women. London: Zed Books.

Christoffersen, Lisbet (2006) "Intertwinement. A new concept for understanding religionlaw relations". Nordic Journal for Religion and Society, 2006, no. 2, pp. 107-126.

Glennon, Theresa (2009) „Divided parents, shared children. Conflicting approaches to relocation disputes in the USA". In K. Boele-Woelki (ed.) Debates in Family Law around the Globe at the Dawn of the $21^{\text {st }}$ Century. Antwerpen: Intersentia.

Hagelund, Anniken (2008) „'For women and children'. The family and immigration politics in Scandinaviau. In R. Grillo (ed.) The Family in
Question. Immigrant and Ethnic Minorities in Multicultural Europe. Amsterdam: Amsterdam University Press.

Harding, Maebh (2008) "'To affinity and beyond'. A critical analysis of the law on marriage within prohibited degrees of relationship«. In K. Boele-Woelki \& T. Svendrup (eds.) European Challenges in Contemporary Family Law. Antwerpen: Intersentia.

Inger, Göran (1980) Svensk rättslära. Lund: Liber Läromedel.

Jänterä-Jareborg, Maarit (1997) Svensk domstol och utländsk rätt. Uppsala: Iustus förlag.

MacEoin, Denis (2009) Sharia Law or 'One Law for All'? London: Civitas.

McGlynn, Clare (2006) Families and the European Union. Law, Politics and Pluralism. Cambridge: Cambridge University Press.

Maxwell, Nancy (2009) "The Kansas case of K.M.H. US law concerning the legal status of known sperm donors". In K. Boele-Woelki (ed.) Debates in Family Law around the Globe at the Dawn of the $21^{\text {st }}$ Century. Antwerpen: Intersentia.

Melby Kari, Pytkkänen Anu \& Rosenbeck Bente (red.) (2006) Inte ett ord om kärlek. Äktenskap och politik i Norden ca 1850-1930. Centrum för Danmarksstudier. Göteborg: Makadam förlag.

Nasir, Jamal J.A. (2009) The Status of Women under Islamic Law and Modern Islamic Legislation. Leiden: Brill.

Phillips, Anne (2007) Multiculturalism without Culture. Princeton: Princeton University Press.

Rabo, Annika (2005) „Family law in multicultural and multireligious Syria». In G. Collste (ed.) Possibilities of Religious Pluralism. Linköping: Linköping University Electronic Press.

Rabo, Annika (2007) "Gränslösa familjer gräns(lös) kontroll». I E. Olsson, C. Lundqvist, A. Rabo, L. Sawyer \& Ö. Wahlbeck (red.) Transnationella rum. Diaspora, migration och gränsöverskridande relationer. Umeå: Borea.

Rabo, Annika (kommande) "Syrian transnational families and family lawu. In S. Ali, A. Griffiths \& A. Hellum (eds.) From Transnational rela-

Annika Rabo: Den goda familjen och den goda familjerätten. 
tions to Transnational Laws. Aldershot: Ashgate.

Scharma, Wendy (2009) "Family function over family form in the law on parentage? «. In K. Boele-Woelki (ed.) Debates in Family Law around the Globe at the Dawn of the $21^{\text {st }} \mathrm{Cen}$ tury. Antwerpen: Intersentia.

Shachar, Ayelet (2001) Multicultural Jurisdictions. Cultural Differences and Women's Rights. Cambridge: Cambridge University Press.

Singer, Anna (2009) „Active parenting or Solomon's justice? Alternative residence in Sweden for children with separated parents». In K. BoeleWoelki (ed.) Debates in Family Law around the Globe at the Dawn of the $21^{\text {st }}$ Century. Antwerpen: Intersentia.

Smith, Lucy (2008) „Recent developments in child laww. In K. Boele-Woelki \& T. Svendrup (eds.) European Challenges in Contemporary Family Law. Antwerpen: Intersentia.

Tsaoussi, Aspasia \& Zervogianni, Eleni (2008)
"Multiculturalism and family law. The case of Greek Muslims». In K. Boele-Woelki \& T. Svendrup (eds.) European Challenges in Contemporary Family Law. Antwerpen: Intersentia.

Thorbjörnsrud, Berit S. (2005) "Innledning». I B. S. Thorjörnsrud (red.) Evig din? Ekteskaps- og samlivstradisjoner $i$ det flerreligiösa Norge. Oslo: Abstrakt forlag.

Waerstad, Tone Linn (2006) Retten til ikke åbli diskriminert ved skilsmisse. En rettsantropologisk studie av skilt muslimske innvandrerkvinner $i$ Norge. Kvinnerettslig skriftserie nr 64. Oslo: Universitetet i Oslo, Avdeling for kvinnerett.

Vonk, Machtelid (2009) »The role of formalised and non-formalised intentions in legal parentchild relationships in Dutch law». In K. BoeleWoelki (ed.) Debates in Family Law around the Globe at the Dawn of the $21^{\text {st }}$ Century. Antwerpen: Intersentia.

\section{Tidningsartiklar}

NRC Handelsblad 2009, juli (Maurits Berger).

Solna församlingsblad 2009, nr 4 (Ingrid Blideman).

Svenska Dagbladet 27.1 2003 (Per Brinkemo).

\section{Internetkällor}

www.norway.org.pk/misc/print.aspx?article.

www.svd.se/opinion/brannpunkt/artikel_1796829.svd

www.dagen.se/Article_Print.aspx?ID=162623

www.ilga-europe.org

www.familylawweek.co.uk/site.aspx?i=ed24572

www.ungdomsstyrelsen.se/art/0,2072,7770,00.html

http://ec.europa.eu/civiljustice/divorce/divorce_ec_en.htm

www.katolsk.no/nyheter/special/blankett-c.htm

www.international-divorce.com/d-israel.htm

www.guardian.co.uk

http://www.hcch.net/index_en.php?act=text.display\&tid=21

http://www.internationalfamilylawfirm.com/2007/11/german-divorce-syrian-marriage.htm 


\section{Summary}

\section{The good family and good family law Debates about law and morals in multicultural Europe}

In this article I discuss how political and social transformations challenge the juridical space of the nation-state. Globalization, in terms of migration and the spread of rights and duties from supranational institutions such as the $\mathrm{EU}$ and the $\mathrm{UN}$, distort taken-for-granted "national" assumptions about which norms and legal prescriptions citizens are supposed to follow when they organize their everyday activities.

The focus in my discussion is on universal social institutions such as marriage and the family. What is marriage and family? What laws and regulations should be used to regulate relations between members of these institutions? I want to show that various religious traditions (Christian, Isla- mic and Jewish) have their own set of definitions and rules. When these rights and duties are confronted with other legal traditions found in Western Europe it is not altogether clear which rules actors should fall back on.

A central theme in my discussion is the discrepancy between the formal legal system and how legal prescriptions are acted upon in the informal everyday life of citizens in the multicultural society. I argue that it is not self-evident how this discrepancy should be overcome, or if this is possible. These questions are, as I show, complex since the state and its citizens often have contradictory views of how a "normal" family is constituted. 